\title{
Technology use among Ghanaian Senior High School students' in learning mathematics and the factors that influence it
}

\author{
M. Agyemang1, E. Hagan² and S. Agyabeng ${ }^{3}$
}

\begin{abstract}
The study sought to investigate technology use among Ghanaian senior high school students' and to also uncover the factors influencing their technology use. A cross-sectional survey design with mixed quantitative and qualitative data was gathered for the study. The population of the study comprised of all senior high school students' in Ashanti region. A stratified sampling technique was used to select 200 students from both rural and urban districts in Ashanti region. The findings revealed that the extent to which SHS students' use technology in learning mathematics was very low. The Independent samples t-test revealed that students' in the urban areas use more technology $($ Mean $=2.19, \mathrm{SD}=0.48)$ than students' in the rural areas (Mean $=1.94, \mathrm{SD}=0.54)$, students' in a school with high technology resources available use more technology (Mean $=2.30$, $\mathrm{SD}=0.48)$ than students' in a school with low technology resources available (Mean $=1.88, \mathrm{SD}$ $=0.50)$ and students' above the age of 20 years use more technology (Mean $=2.61, \mathrm{SD}=0.59$ ) than students' within the age of $18-20$ years (Mean $=2.03, \mathrm{SD}=0.56)$ and students' within the age of $15-17$ years $($ Mean $=2.08, \mathrm{SD}=0.44)$. The analysis revealed that the differences in the mean technology use between students' in the rural and urban areas, students' in schools with high technology resources available and students' in schools with low technology resources available and students' above 20 years and students below 20 years were statistically significance $(\mathrm{F}=12.22, \mathrm{p}=0.001),(\mathrm{F}=35.91, \mathrm{p}=0.00)$, and $(\mathrm{F}=4.96, \mathrm{p}=0.01)$ respectively.
\end{abstract}

Key words technology use, technology integration, learning mathematics,

\section{Introduction}

Technology integration has become a catch phrase in education today. The call to integrate Information and Communication Technology (ICT) in education has become a major concern to Education stakeholders and policymakers across the world. From the early 1990s, education stakeholders in Ghana have been concerned about how teachers and students use computers in schools and how their use supports learning (Boakye \& Banini, 2008). In the middle of the 1990s, educational providers realized that Ghanaian professionals could not compete on the global market for jobs, because they were limited in skill, especially in the area of Information Technology (Nyarko, 2007).In view of this, the World Links for Development (WorLD) programme was introduced in Ghana, in 1997. This programme was designed to use technology to open a world of learning for teachers and students. The programme aims to assist teachers and students to integrate

\footnotetext{
${ }^{1}$ Moses Agyemang, Department of Mathematics/ICT, Akrokerri College of Education, Akrokerri-Ashanti. ${ }^{2}$ Ekow Hagan, Department of Mathematics, Methodist College of Education, Akin Oda-Eastern. Email: hagan228@gmail.com

${ }^{3}$ Stephen Agyabeng, Department of Mathematics, Offinso College of Education, Offinso-Ashanti. Email: steveagvabeng $a$,gmail.com
} 
Technology use among Ghanaian Senior High School students' in learning mathematics and the factors that influence it

\section{Agyemang, E. Hagan and S. Agyabeng}

technology into their curricula, to facilitate collaborative projects and distance learning among teachers and students, to assist students in using computers and the internet as communication and research tools, and to develop local educational content on the internet (Kwei, 2001).

Several studies have highlighted students' use of technology in mathematics instruction and the factors that influence their use. Faekah and Ariffin (2005) surveyed 554 Form Four students to find out gender differences in computer attitude and skills. Their findings revealed that students were not skillful in computing. Only $17.9 \%$ of the students Send messages via e-mail, 16.4\% Search for information on the web and 20.6\% Print documents or images. Similarly, Kaino and Salani (2004) surveyed 40 students to investigate gender attitudes towards the use of calculators in mathematics instruction in Botswana. Their findings indicated that majority of students used and enjoyed working with calculators. However, Boakye and Banini (2008) conducted a study to find out the level of technology use by Ghanaian students. Out of the 5048 students surveyed, the findings indicated that $62 \%$ use the computer for general knowledge while $13 \%$ use it for academic purposes. Their findings further revealed that $13 \%$ of the students use it for communication whereas $10 \%$ use it for research. These findings indicate that technology use is gradually gaining grounds among Ghanaian students. Also, Chu, (2004) argued that students' perceived usefulness of technology in learning is highly dependent of teachers' actual implementation of technology in the mathematics classrooms. Students would not be motivated to use technology unless they have had enough hands-on experience in using some mathematics software or websites in the school.

Besides, several studies have highlighted the factors that influence students' technology use in learning mathematics. Sarfo, et.al (2011) conducted a study to investigate Rural and urban students' attitudes towards information and communication technology in Ghana. Out of the 324 SHS students sampled, the findings revealed that the locality of the male and female students does not influence their attitudes towards technology. Mereku et 'al (2009) also conducted a study to investigate pedagogical integration of ICT. Their findings revealed that availability of ICT syllabuses/manual, computers and computer laboratories that can be accessed periodically were factors that influence technology use at the SHS level in Ghana Their analysis further revealed that students' attitudes towards technology do not differ in terms of gender. Besides, Kahveci, (2010) conducted a study to find out students' perceptions to use technology for learning. Out of 158 students surveyed, the findings revealed that Female students were less confident in using technology compared to male students. He therefore found a significant difference $F(1,158)=$ $6.300, p=.014$ in the effect of Confidence between male and female students. Similarly, Venkatesh and Morris (2000) conducted a study to investigate Gender, social influence, and their role in technology acceptance and usage behavior. Their findings revealed that men emphasized more on perceived usefulness in determining behavioral intention to use, while women regarded perceived ease of use as a more significant factor in determining behavioral intention to use. Furthermore, Nor (2004) used a qualitative methodology to study conditions that facilitated the implementation of information and communication technology integration in the Malaysian secondary school curriculum. The findings revealed that two sets of conditions: (i) essential conditions (such as availability of technology resources and acquisition of technology knowledge), and (ii) supporting conditions (such as accessibility of technology resources, presence of support, desire to change among teachers, school practices, influence of external forces and teachers' commitment to the innovation) significantly influence the teachers' technology use. Besides, Norris et.al (2003) surveyed rural and urban respondents in California, Florida, Nebraska, and New York to investigate the extent of technology use in K-12 in U.S. Out of the 3,665 teachers surveyed, the 
analysis revealed that appropriate access to technology infrastructure is a key factor in the effective technology integration process. The study revealed substantive correlation between technology access and use.

The government of Ghana in collaboration with the Ministry of Education Science and Sports has made provisions to ensure that Senior High School (SHS) students get access to quality education which takes into accounts the integration of ICT in instruction. For instance, there has been an ICT for Accelerated Development (ICT4AD) policy which seeks to provide a framework in which information and communication technologies will be used to transform the educational sector, allowing all Ghanaians to pursue quality life-long learning opportunities regardless of their geographical location (Republic of Ghana, 2003). Besides, the new educational reform in Ghana which was launched in September, 2007 has also placed high emphasis on the integration of ICT in all subject areas (MOESS, 2007). At least eleven (11) specific objectives in both Core and Elective SHS mathematics syllabus emphasized the need to use spreadsheet in drawing graphs and calculating means, mode, median and standard deviation (MOESS, 2010). Furthermore, there has been an increase of computer laboratories at all levels of the school system and this testify to the potency of the use of computer technology in education delivery (Yidana \& Asiedu-Addo 2001). Also, ICT has currently become a compulsory (core) subject for every SHS student in Ghana.

Due to the above mentioned efforts put up by education stakeholders and policymakers in Ghana to ensure the use of technology in learning, it is believed that the students' will integration technology in learning mathematics. This is so, because the mathematics curriculum in particular emphasizes the integration of technology in learning mathematics. It is in the light of this that the researcher conducted the study to investigate the extent to which Ghanaian SHS use technology in learning mathematics and also uncovered the factors that influence it. The study was guided by the following research questions:

1. To what extent do SHS students use technology in learning mathematics?

2. Which factors (gender, age, number of years in school, school location, availability of technology resources) influence SHS students' technology use in learning mathematics?

\section{Methodology}

The population of the study comprised of all public Senior High School (SHS) students' in the Ashanti region of Ghana. Stratified sampling technique was used to select 200 students from the Ashanti region. The researcher divided Ashanti region into urban and rural districts. A simple random sampling technique was employed to select five (5) SHS from urban districts and five (5) SHS from the rural districts. Twenty (20) students were then selected from each school in both rural and urban districts making a total of 200 students.

\section{Instrument}

After a careful review of appropriate literature, questionnaire was chosen as the instrument to collect data to answer the questions set for this study. It was self-administered questionnaire. It was structured questionnaire that consisted of close format, open-ended format and rating scale type of questions. The questionnaire was based on the technology requirement in the SHS mathematic curriculum. To check for the validity of the instrument, the researcher allowed two (2) senior lecturers who were experts in the field of educational technology and mathematics at the Department of Mathematics Education in the University of Education, Winneba (UEW) to 
Technology use among Ghanaian Senior High School students' in learning mathematics and the factors that influence it

M. Agyemang, E. Hagan and S. Agyabeng

evaluate the questionnaire for content and construct as well as face validity. After the panel's feedback was received, the necessary changes to the content of the questionnaire were made. Later, the improved questionnaire was pilot-tested to establish not only its reliability but also to identify defective items, and ensured that the instrument was clearly understood by respondents.

\section{Pilot Test}

A pilot test of a survey questionnaire is a procedure in which a researcher makes changes in an instrument based on feedback from a small number of individuals who complete and evaluate the instrument (Creswell, 2012). The questionnaire was then administered personally to the students. The questionnaire was administered personally to help improve the collection and response rate of the questionnaire. The responses from the questionnaire items were coded and analyzed through the use of Statistical Package for Social Science (SPSS) software version 16.0.The data entries were done by the researcher in order to check the accuracy of the data. Data were cleaned before running any analysis. Descriptive statistics such as percentage scores were calculated for participants' responses to frequency of technology use in learning. Independent samples t-test and One-way ANOVA were used to test the null hypothesis that "there is no significant difference between the categories for each of the demographic factors on the students' technology use.

\section{Results}

\section{SHS students' use of technology in learning mathematics}

The study was conducted to find out the extents to which SHS students use technology in learning mathematics. To answer this question, the students' general use of technology; their use of computer in learning mathematics; and their use of calculator in learning mathematics; were examined. The students were made to respond to five-point Likert scale items (Everyday, Once a week, Once a month, Once a term, Never) on the frequency of engaging in various activities that involve technology.

The Likert scale with five options which was used to score frequency of students' technology usage was further re-coded into a Likert scale with three options (Often, Rarely, Never). Never and Once a term were re-coded into Never, Once a month was re-coded into Rarely and Once a week and Everyday were re-coded into Often. For each of the technology items computed, the mean score ranged from 0 (minimum) to 2(maximum). A mean score of 0 indicated Never, 1 indicated Rarely and 2 indicated Often: a mean value of 1.0 is considered to be a middle point; a mean value below 1.0 indicates a low level of technology use and a mean value above 1.0 indicates a high level of technology use.

SHS students' general use of technology

Table 1 shows the percentage of usage by students in the various ICT applications. 


\begin{tabular}{lcccccc}
\hline & \multicolumn{3}{c}{ Students' ratings of their general use of technology } \\
\cline { 2 - 7 } & \multicolumn{2}{c}{ Often } & \multicolumn{3}{c}{ Rarely } & \multicolumn{2}{c}{ Never } \\
Item & $\mathrm{N}$ & $\%$ & $\mathrm{~N}$ & $\%$ & $\mathrm{~N}$ & $\%$ \\
\hline $\begin{array}{l}\text { 1. Communicating with friends (e.g. } \\
\quad \text { Facebook, yahoo messenger, Skype }\end{array}$ & 82 & $(40.0)$ & 16 & $(8.0)$ & 101 & $(50.8)$ \\
$\begin{array}{l}\text { 2. Using calculator in the mobile phone for } \\
\quad \text { calculations }\end{array}$ & 65 & $(34.2)$ & 58 & $(30.5)$ & 67 & $(35.3)$ \\
3. Finding information on the internet to do & 50 & $(25.4)$ & 21 & $(10)$. & 126 & $(64.0)$ \\
$\quad$ assignment & 48 & $(24.2)$ & 25 & $(12.6)$ & 125 & $(63.1)$ \\
4. Sending email & 24 & $(12.2)$ & 16 & $(8.1)$ & 157 & $(79.7)$ \\
5. Creating spreadsheet (MS Excel) & 23 & $(11.7)$ & 19 & $(9.7)$ & 154 & $(78.6)$ \\
6. Preparing assignment using MS word & 16 & $(8.0)$ & 19 & $(9.5)$ & 164 & $(82.4)$ \\
7. Attaching files to email message & 15 & $(7.5)$ & 9 & $(4.6)$ & 170 & $(87.6)$ \\
8. Making presentation (PowerPoint) & 6 & $(3.1)$ & 3 & $(1.6)$ & 182 & $(95.3)$ \\
9. Creating database (MS Access) & & & & & &
\end{tabular}

Table 1 shows that very few of the students use technology to communicate with friends (e.g. Facebook, yahoo messenger, Skype) (40.0\%), use calculator in the mobile phone for calculation (35.3\%), create database (MS Access) (3.1\%), make presentation (PowerPoint) $(7.5 \%)$, and attach files to email message (8.0\%). The students' general use of technology had a mean score of 0.49 and a standard deviation of 0.37 . This indicates that SHS students' use of technology in general computer applications is very low.

Students' use of computer in learning mathematics

The second subheading considered was SHS students' use of computer in learning mathematics.

The students' use of computer in learning mathematics is represented in Table 2

\section{Table 2 Proportion of students' rating of their use of computer in learning mathematics as often, rarely or never}

\begin{tabular}{lccccccc}
\hline & \multicolumn{3}{c}{ Students' ratings of their use of computer in } \\
\cline { 2 - 7 } & \multicolumn{3}{c}{ Often } & \multicolumn{3}{c}{ Rarely } & \multicolumn{3}{c}{ Never } \\
Item & $\mathrm{N}$ & $\%$ & $\mathrm{~N}$ & $\%$ & $\mathrm{~N}$ & $\%$ \\
\hline 1. Investigating the nature of graph of functions & 6 & $(3.0)$ & 6 & $(3.0)$ & 186 & $(93.9)$ \\
2. Drawing graphs of grouped data & 10 & $(5.0)$ & 8 & $(4.0)$ & 180 & $(90.9)$ \\
3. Drawing graphs of logarithmic functions & 1 & $(0.5)$ & 1 & $(0.5)$ & 196 & $(99.0)$ \\
4. Drawing graphs of trigonometric functions and & 0 & $(0)$ & 1 & $(0.5)$ & 196 & $(99.5)$ \\
$\quad$ find their solutions & & & & & & \\
5. Drawing scatter diagram for bivariate & 0 & $(0)$ & 0 & $(0)$ & 198 & $(100)$ \\
\hline
\end{tabular}


Technology use among Ghanaian Senior High School students' in learning mathematics and the factors that influence it

M. Agyemang, E. Hagan and S. Agyabeng

The results in Table 2 show that majority of SHS students never or rarely used computer in learning mathematics. Very few students used computer to draw graphs of grouped data $(5.0 \%)$ and to investigate the nature of graph of functions (3.0\%). None of the students use computer to draw graphs of trigonometric functions and find their solutions and also draw scatter diagram for bivariate distributions. The students' use of computer in learning mathematics had a mean score of 0.05 and a standard deviation of 0.17 . This indicates that the extent to which SHS students use computer in learning mathematics is very low.

Students' use of calculator in learning mathematics

The third subheading considered was SHS students' use of calculator in learning mathematics. Table 3 shows proportion of students' use of calculator in learning mathematics.

Table 3 Proportion of students' ratings of their use of calculator in learning mathematics as often, rarely or never

\begin{tabular}{lccccccc}
\hline & \multicolumn{5}{c}{ Students' ratings of their use of calculator in } \\
& \multicolumn{7}{c}{ learning mathematics } \\
\cline { 2 - 7 } & \multicolumn{3}{c}{ Often } & \multicolumn{3}{c}{ Rarely } & \multicolumn{2}{c}{ Never } \\
Item & $\mathrm{N}$ & $\%$ & $\mathrm{~N}$ & $\%$ & $\mathrm{~N}$ & $\%$ \\
\hline $\begin{array}{l}\text { 1. Expressing recurring decimals as common } \\
\text { fractions }\end{array}$ & 132 & $(66.0)$ & 12 & $(6.1)$ & 54 & $(27.3)$ \\
$\begin{array}{l}\text { 2. Calculating the mean, median and standard } \\
\text { deviation }\end{array}$ & 115 & $(58.4)$ & 10 & $(5.1)$ & 72 & $(36.5)$ \\
$\begin{array}{l}\text { 3. Determining the depreciation of an item } \\
\text { over a period of time }\end{array}$ & 94 & $(47.5)$ & 12 & $(6.1)$ & 92 & $(46.5)$ \\
$\begin{array}{l}\text { 4. Finding the value of cos inverse of halve } \\
\left(\cos ^{-1}\left(\frac{1}{2}\right)\right)\end{array}$ & 117 & $(59.1)$ & 8 & $(4.0)$ & 73 & $(36.9)$ \\
\hline
\end{tabular}

The results in Table 3 show that SHS students often use calculator in learning mathematics. Majority of the students indicated that they often used calculator to: express recurring decimals as common fractions $(66.0 \%)$, calculate the mean, median and standard deviation $(58.4 \%)$, find the value of cos inverse of halve $\left(\cos ^{-1}\left(\frac{1}{2}\right)\right)(59.1 \%)$ and determine the depreciation of an item over a period of time (47.5\%) when asked of their frequency of calculator use for learning mathematics. The students' use of calculator in learning mathematics had a mean score of 1.22 and a standard deviation of 0.77 . This indicates that SHS students' use of calculator in learning mathematics is high.

The open-ended items in the students' questionnaire revealed that the students were not allowed to use the computer laboratory after classes and during weekends. However, they were only allowed to use the computer laboratory once every week.

\section{Factors that influence SHS students' technology use in learning mathematics}

The overall mean score of students' technology use was computed from their ratings on a fivepoint Likert scale. This was used as the proxy score for the SHS students' technology use in learning mathematics. For each of the technology items computed, the mean score ranged from 1 (minimum) to 5 (maximum). A mean value below 3.0 indicates a low level of technology use and a mean value above 3.0 indicates a high level of technology use. Table 4 shows the overall mean 
score of students' technology use in learning mathematics.

Table 4 Mean score of students' technology use in learning mathematics

\begin{tabular}{lccccc}
\hline & N & Minimum & Maximum & Mean & Std. Deviation \\
\hline $\begin{array}{l}\text { Students technology use in } \\
\text { learning mathematics }\end{array}$ & 200 & 1 & 5 & 2.07 & 0.53 \\
\hline
\end{tabular}

The results from Table 4 show that the students' overall use of technology in learning mathematics is low since the mean score of 2.07 is below 3.0 and the standard deviation of 0.53 meaning most of the students rated their technology use close to zero or Never.

The second question raised in this study was to find out which of the demographic factors (i.e. gender, age, number of years in school, school location and availability of technology resources) influence students' technology use in learning mathematics. To determine this, the mean technology use of the categories in each of the factors was computed (see Table 5). To answer this question, the mean scores of the students' technology use were analyzed for differences in the categories for each of the five demographic factors - gender, age, number of years in school, school location and availability of technology resources. One-way analysis of variance (ANOVA) was used to test the null hypothesis that "there is no significant difference between the categories for each of the five demographic factors on the teachers' technology use". Table 5 presents the OneWay ANOVA test results on factors influencing students' technology use in learning mathematics.

Table 5 Factors influencing students' technology use in learning mathematics

\begin{tabular}{|c|c|c|c|c|c|c|c|}
\hline Factor & Categories & $\mathrm{N}$ & Mean & $\begin{array}{c}\text { Std. } \\
\text { Deviation }\end{array}$ & Df & $\mathrm{F}$ & Sig. \\
\hline \multirow[t]{2}{*}{ Gender } & Female & 87 & 2.01 & 0.43 & \multirow{2}{*}{198} & \multirow{2}{*}{2.07} & \multirow{2}{*}{0.15} \\
\hline & Male & 113 & 2.11 & 0.59 & & & \\
\hline \multirow[t]{3}{*}{ Age } & $15-17$ years & 78 & 2.08 & 0.44 & \multirow{3}{*}{191} & \multirow{3}{*}{4.69} & \multirow{3}{*}{0.01} \\
\hline & $18-20$ years & 108 & 2.03 & 0.56 & & & \\
\hline & $\begin{array}{l}\text { Above } 20 \\
\text { years }\end{array}$ & 8 & 2.61 & 0.59 & & & \\
\hline \multirow{3}{*}{$\begin{array}{l}\text { Number of years } \\
\text { in school }\end{array}$} & Year two & 51 & 2.07 & 0.53 & \multirow{3}{*}{197} & \multirow{3}{*}{3.03} & \multirow{3}{*}{0.05} \\
\hline & Year three & 77 & 2.00 & 0.52 & & & \\
\hline & Year four & 72 & 2.12 & 0.51 & & & \\
\hline \multirow[t]{2}{*}{ School Location } & Rural & 100 & 1.94 & 0.54 & \multirow{2}{*}{198} & \multirow{2}{*}{12.22} & \multirow{2}{*}{0.001} \\
\hline & Urban & 100 & 2.19 & 0.48 & & & \\
\hline \multirow{2}{*}{$\begin{array}{l}\text { Availability of } \\
\text { Technology } \\
\text { Resources }\end{array}$} & $\begin{array}{l}\text { Low resources } \\
\text { available }\end{array}$ & 112 & 1.88 & 0.50 & \multirow{2}{*}{198} & \multirow{2}{*}{35.91} & \multirow{2}{*}{0.00} \\
\hline & $\begin{array}{l}\text { High resources } \\
\text { available }\end{array}$ & 88 & 2.30 & 0.47 & & & \\
\hline
\end{tabular}

*Significant $(\mathrm{p}<0.05),{ }^{* *}$ Highly Significant $(\mathrm{p}<0.001)$

It can be observed from Table 5 that there are differences in the mean scores in the categories of the various factors, but the differences in the mean scores of age $(F=4.96, p=0.01)$, school location $(F=12.22, p=0.001)$ and availability of technology resources $(F=35.91, p=0.00)$ were found to be statistically significant. Therefore, the null hypotheses that there are no significant 
Technology use among Ghanaian Senior High School students' in learning mathematics and the factors that influence it

M. Agyemang, E. Hagan and S. Agyabeng

differences between or among the categories of the three factors - age, school location and availability of technology resources were rejected. Hence, we accept the alternated hypotheses that age, school location and availability of technology resources statistically influence SHS students' technology use in learning mathematics.

\section{Discussion}

The study was conducted to investigate the extent to which Ghanaian SHS students' use technology in learning mathematics and to also uncover the factors that influence it. The findings revealed that the students often use calculator to express recurring decimals as fractions, to calculate the mean, median and standard deviation, to determine the depreciation of an item over a period of time and to find the value of $\cos$ inverse of halve $\left(\cos ^{-1}\left(\frac{1}{2}\right)\right)$. This finding is consistent with the findings of Kaino and Salani (2004) who revealed that majority of students in Botswana used and enjoyed working with calculators. The finding further revealed that the students overall use of technology in general computer applications and in learning mathematics is very low. This finding is in consonance with the findings from Boakye and Banini (2008) who concluded that SHS student use of technology in academic purposes, communication and research is very low. Faekah and Ariffin (2005) also found out that students were not skillful in computing. Very few of them send messages via e-mail, search for information on the web and print documents or images.

It is not surprising that the extent to which the students use technology in learning mathematics is very low, because the open-ended items in the questionnaire revealed that the students are not allowed to use the computer laboratory after classes and during weekends. However, the students are allowed to use the computer laboratory once every week. Besides, the extent to which the mathematics teachers use technology in teaching is very low and this might affect the students' use of technology in learning mathematics. Chu, (2004) argued that students' perceived usefulness of technology in learning is highly dependent of teachers' actual implementation of technology in the mathematics classrooms. Students would not be motivated to use technology unless they have had enough hands-on experience in using some mathematics software or websites in the school.

Furthermore, the study also investigated the factors that influence SHS students' technology use in learning mathematics. The findings revealed that that age statistically influence students technology use in learning mathematics. The finding is in consonance with the findings of a similar study conducted by Al-Ghaith, Sanzogni, and Sandhu, (2010) who found that age has a significant influence on people's access to and use of the Internet and its services. The mean differences in the age usage revealed that SHS students who were above 20 years use more technology than their colleagues who were below 20 years. The mean differences in their technology use might be due to the fact that those students above 20 years were exposed to technology earlier before their colleagues, since these students are probably in Form 3 and Form 4.

The findings also revealed that location of the school statistically influence students' technology use in learning mathematics. This finding is in consonance with the findings of Cassim and Eyono Obono (2011) who found out that school location statistically influence technology adoption in South African high schools. The differences in the mean usage between rural and urban students in Ghana might be due to the fact that urban students have more access to technology than their colleagues in the rural districts. All the students from the rural districts indicated that they have no 
internet in their schools while over $50 \%$ of the students from urban districts indicated that they have internet in their schools.

The findings further revealed that availability of technology resources statistically influence students' technology use in learning mathematics. This finding is consistent with the findings of Mereku et al (2009) who found out that the availability of technology resources such as ICT syllabuses/manual, computers and computer laboratories have a significant influence in students' technology use at the SHS level in Ghana. Similarly, Nor (2004) found that availability of technology resources facilitate the implementation of information and communication technology integration in the Malaysian secondary school curriculum. Besides, Crisan (2004) found out that the availability of technology facilities is a contextual factor that influences technology use in mathematics. The finding is in consonance with Valsiner's (1997) zone of Free Movement which indicates that the availability of different objects within an accessible area, and the ways the individual is permitted or enabled to act with accessible objects in accessible areas influences the person's technology use. However, high technology resources available in a particular school will influence the students' technology use. The differences in the mean usage revealed that Ghanaian SHS students with high technology resources available use more technology than their colleagues with low technology resources available. The reason for such a finding could be that students having high technology resource available might definitely use more technology than their colleagues with low technology resources available.

\section{Conclusion}

The study revealed that the extent to which SHS students use technology in learning mathematics was very low. This was also found to be due to the fact that the students were not allowed to use the computer laboratory after classes and during weekends but only allowed to use the laboratory once every week. It was also attributed to the low technology use in teaching among mathematics teachers which consequently affects the students' use of technology in learning mathematics.

The study further revealed that age, school location and availability of technology resources statistically influence SHS students' technology use in learning mathematics. Whereas, gender and number of years in school did not statistically influence their technology use. In view of this, the researcher has made the following recommendations.

\section{Recommendations}

From the summary of the major findings of this study, it is recommended that: the Ministry of Education should make budgetary allocations annually to maintain, replace and expand ICT facilities and resources in the schools in order to promote effective integration in the teaching and learning process. The Ministry of Education should emphasize the use of computer laboratory during weekends and after classes as part of the co-curricular activities in the secondary schools. The Teacher Education Division should review ICT programmmes of the teacher education institutions to enable prospective teachers to develop ICT integration skills.

\section{Limitation}

The findings of this study should not be generalized to all SHS students in Ghana, as the respondents involved were students in Ashanti region of Ghana. This population was selected because of ease of accessibility due to time constraint and limited financial resources. Thus, this places a limitation on the generalization that could be made on the findings of this study. 
Technology use among Ghanaian Senior High School students' in learning mathematics and the factors that influence it

M. Agyemang, E. Hagan and S. Agyabeng

\section{References}

Al-Ghaith, W., Sanzogni, L. and Sandhu, K. (2010). Factors Influencing The Adoption And Usage Of Online Services In Saudi Arabia. The Electronic Journal on Information Systems in Developing Countries EJISDC (2010) 40, 1, 1-32.

Boakye, K.B., \& Banini, D.A. (2008). Teacher technology Readiness in Ghana. In K. Toure, T.M.S. Tchombe, \& T. Karsenti (Eds.), technology and Changing Mindsets in Education. Bamenda, Cameroon: Langaa; Bamako, Mali: ERNWACA / ROCARE.

Cassim, K. M. and Eyono Obono S. D. (2011). On the Factors Affecting the Adoption of technology for the Teaching of Word Problems. Proceedings of the World Congress on Engineering and Computer Science 2011 Vol I WCECS 2011, October 19-21, 2011, San Francisco, USA

Chu, S., B. (2004). Factors affecting the perceived usefulness of information technology in mathematics learning and teaching. Retrieved on $6^{\text {th }}$ April 2012 from http://hub.hku.hk/bitstream/10722/31911/1/FullText.pdf

Creswell, J., W. (2012). Educational Research: Planning, Conducting and Evaluating Quantitative and Qualitative Research, (4 ${ }^{\text {th }}$ edn). Boston: Pearson Education, Inc.

Crisan, C. (2004). Mathematics teachers' learning about and incorporation of technology into classroom practices. McNamara, O. (Ed.) Proceedings of the British Society for Research into Learning Mathematics 24(2) June 2004. Retrieved on March, 17, 2011 from http://www.bsrlm.org.uk.com/

Faekah, T. and Ariffin, T. (2005). Gender Differences in Computer Attitudes and Skills. Jurnal Pendidikan 3075 - 91 .

Kahveci, M. (2010). Students' Perceptions To Use Technology For Learning: Measurement Integrity Of The Modified Fennema-Sherman Attitudes Scales. The Turkish Online Journal of Educational Technology volume 9, 185 - 201

Kaino, L., M. and Salani, E., B. (2004). Students' gender attitudes towards the use of calculators in mathematics instruction. Proceedings of the 28th Conference of the International Group for the Psychology of Mathematics Education, 2004 Vol 3 pp 113-120

Kwei, C.B.L. (2001) WorLD Ghana: Computer conflict, world ICT access. [Online]. Available: www.iconnectonline.org/Stories/Story.import109

Mereku, D. K., Yidana, I, Hodzi, W., Tete-Mensah, I., Tete-Mensah, W., and Williams, J. B. (2009). Pan-African Agenda on Pedagogical Integration of ICT: Phase 1 Ghana report. University of Education, Winneba. Canada: International Development Research Centre (IDRC)

Ministry of Education, Science and Sports. (2007). Teaching syllabus for mathematics

(Senior High School). Accra: Curriculum Research and Development Division (CRDD).

Ministry of Education, Science and Sports. (2010). Teaching syllabus for mathematics (Senior High School). Accra: Curriculum Research and Development Division (CRDD). 
Nor, H., M. (2004). Conditions facilitating the implementation of technology integration in the Malaysian secondary school curriculum. Unpublished doctoral thesis, Universiti Putra Malaysia, Serdang, Malaysia

Norris, C., Sullivan, T., Poirot, J., \& Soloway, E. (2003). No access, no use, no impact: Snapshot surveys of educational technology in $K-12$. Journal of Research on Technology in Education, 36(1), 15-27

Nyarko E, (2007). Developing ICT enabled education -the future for Ghana: I Retrieved on March 12, 2010 from http://www.iconnect online.org/Documents/Ghana\%20Elearning\%202007\%20eng\%20iConnect.pdfNorris,

Republic of Ghana. (2003). The Ghana ICT for accelerated development (ICT4AD) policy. Accra, Ghana: Graphic Communications Group Limited

Sarfo, F., K., Amartei, A., M., Adentwi, K., I. and Brefo, C. (2011). Technology and gender equity: Rural and urban students' attitudes towards information and communication technology. Journal of Media and Communication Studies Vol. 3(6), pp. 221-230. Available online http://www.academicjournals.org/jmes

Valsiner, J. (1997). Culture and the development of children's action: A theory of human development. (2nd ed.). New York: John Wiley \& Sons.

Venkatesh, V. \& Morris, M.G. (2000). Why do not men ever stop to ask for directions? Gender, social influence, and their role in technology acceptance and usage behavior. MIS Quarterly, 24(1), 115-139

Yidana, I \& Asiedu-Addo, S.K, (2001). The Use of Information Technology in Teacher Education. Mathematics Connections. Vol.2, 30-34 